\title{
Macbeth, the Real Devil
}

\author{
Zhang Tong, Tian Jianguo, and Wang Fangyuan
}

\begin{abstract}
As one of the four great tragedies of Shakespeare, Macbeth has always been the classic drama of Shakespeare. Macbeth, who changes himself from a heroic and respected general to a usurper, has caused people to think about his tragic fate. Lady Macbeth and the witch were always spurned and reviled for their seduction. However, it is impossible for Macbeth to be controlled by the witches and Lady Macbeth. His evil ambitions make himself the real devil, which is the primary factor of the tragedy. Lady Macbeth and witches are just scapegoats.
\end{abstract}

Index Terms - Macbeth, Lady Macbeth, witch, patriarchy.

\section{INTRODUCTION}

Macbeth is one of Shakespeare's four great tragedies. It was based on Holinshed's The Chronicles of England, Scotland and Ireland. He expressed his deep thoughts to the social reality and human nature, dreaming of punishing evil-doers. In this tragedy, Macbeth is a brave and famous Scottish general in 11th century. But he is seduced by three witches who say that one day Macbeth will become King of Scotland. After that, Macbeth murders King Duncan and takes the Scottish throne for himself. He is then tortured by guilt and fear of revengers. To protect himself and his throne, he commits more and more murders, and he soon becomes a tyrannical ruler. At the end, he is killed by the revengers and his wife died of madness.

\section{Purposes OF THE RESEARCH}

Macbeth is a brave and famous warrior, and one of the nobility. He is respected by all the people including the King Duncan of Scotland. It is hard to imagine that, in order to realize the witch's prophecy, "the Future King", Macbeth takes the butcher's knife, breaks the peace, and brings blood to his country. He becomes a crazy butcher who is eager for power and throne.[1] Macbeth uses his courage and wisdom to get the high status and reputation. But what turns such a brave and noble general into a bloody tyrant?

Many people believe that the tragic ending of the protagonist Macbeth is caused by witches' and Lady Macbeth's seduction. These views are biased. Therefore, this research is to make an analysis on the roles of Lady Macbeth, Three Witches, and Macbeth, to prove that the destruction of Macbeth is mainly caused external factors rather than his own. The lure of witches and Lady Macbeth does play a role in the destruction of Macbeth, but that's not the main factor. The main factor is Macbeth's ambition, and lust for power. As the

Manuscript received July 24, 2018; revised September 17, 2018.

The authors are with the Northwestern Polytechnical University, China (e-mail: 13201761015@163.com). king slayer, Macbeth ended up being destroyed, and the whole play ended with justice and the order of the society is restored.

\section{METHODS}

This research is based on the original text of Macbeth by Shakespeare. Then this research makes a comparative study by comparing the different degrees of how much Lady Macbeth, Three Witches and Macbeth contribute to the tragedy of Macbeth. Therefore, in the analysis part, there are two contrasts. The first one is between Lady Macbeth and Macbeth, and the second one is between Three Witches and Macbeth. From these two contrasts, it can be obviously shown the conclusion of this research.

\section{ANALYSIS}

\section{A. Macbeth and Lady Macbeth}

As it is said at the beginning of The Tragedy of Macbeth, "Fair is foul, and foul is fair, Hover through the fog and filthy air", the tragedy is happened in a black and turbulent background. The comments on this tragedy are also indiscriminate. Lady Macbeth and the witches are blamed for seducing Macbeth to do evil murders. However, after analyzing this tragedy, it is found that the main cause of the destruction of Macbeth is neither Lady Macbeth nor three witches, but the evil in Macbeth's heart. Lady Macbeth just pushes Macbeth to carry out the murder, and her existence is to make Macbeth more firm about his evil ambition. [2]

Firstly, Macbeth has the evil ambition to the king before the persuasion of Lady Macbeth. Before Macbeth decides to murder the King Duncan, he hesitates and feels afraid of what he is going to do. At this time, it seems that Lady Macbeth plays an important role by helping Macbeth make up his mind to murder the King Duncan. As Macbeth's wife, she clearly knows the weakness of his character. So she says:

\section{Thou wouldst be great}

Art not without ambition, but without

The illness should attend it: what thou wouldst highly,

That wouldst thou holily; wouldst not play false,

And yet wouldst wrongly win: thou'ldst have, great Glamis

She points out the ambition of Macbeth which may not be admitted by Macbeth before. At the same time, Lady Macbeth uses some words to irritate Macbeth to push him to make up his mind:

\section{Art thou afeard}

To be the same in thine own act and valour 
As thou art in desire? Wouldst thou have that

Which thou esteem'st the ornament of life,

And live a coward in thine own esteem,

Letting'I dare not'wait upon'I would,

Like the poor cat i'the adage?

She says Macbeth is a coward and like a poor cat, which greatly irritates Macbeth who feels humiliated. After that, he makes the decision to murder the King Duncan.

From what is stated above, it seems that it is Lady Macbeth that makes Macbeth take the butcher's knife to the King and take the throne. However, we just observe the surface of this tragedy. Actually, Macbeth does have the ambition and evil to murder the King before the persuasion of Lady Macbeth. When Macbeth is proclaimed to be Cawdor, he says "Two truths are told. As happy prologues to the swelling act of the imperial theme... My thought, whose murder yet is but fantastical, shakes so my single state of man..." At that time, Macbeth believes he definitely would be the king and thinks about murder.

Meanwhile, if we explore why Macbeth hesitates and gets afraid of what he is going to do, we can find the great evil hidden in the bottom of his heart. When the King Duncan is at Macbeth's home, Macbeth feels:

\section{Besides, this Duncan \\ Hath borne his faculties so meek, hath been \\ So clear in his great office, that his virtues \\ Will plead like angels, trumpet - tongued, against \\ The deep damnation of his taking-off;}

From these words, we can find that Macbeth gets afraid of murdering the King Duncan because he is afraid that his murder will be revealed and his good reputation will be destroyed at all. The King Duncan is widely loved by the people, if people find he is murdered by Macbeth, Macbeth will be widely recognized as a devil.

Also, Macbeth has a soliloquy:

With his surcease success; that but this blow

Might be the be-all and the end-all here,

But here, upon this bank and shoal of time,

We'ld jump the life to come. But in these cases

We still have judgement here; that we but teach

Bloody instructions, which, being taught, return

To plague the inventor: this even-handed justice

Commend the ingredients of our poison'd chalice

To our own lips.

From these words, we can find that Macbeth gets afraid not only because that he values reputation, but also because he fears the revengers. He worries about he may "plague the inventor".Macbeth believes the murder will be revenged according to the taught rule of justice. When he kills Duncan and becomes the king, he may also be murdered in the same way. Therefore, Macbeth hesitates and gets afraid because he values his reputation and he fears revengers.

Obviously, these two reasons are totally related to Macbeth's own interests. When considering whether he should murder the King or not, Macbeth is only concerned about himself rather than the justice and morals, which clearly indicates the evil in his heart. However, for Lady Macbeth, she only urges Macbeth to take action because Macbeth seems to hesitate. The main motivation of Macbeth's decision to murder the King is the evil ambitions in his heart. After hesitation, he says "I dare do all that may become a man. Who dares do more is none." His words show his courage and determination, which further and truly presents what is hidden in his heart.

Besides, when Duncan announces his eldest son is named the Prince of Cumberland, Macbeth shows his evil. He calls the Prince of Cumberland "a step on which I must fall down or else o' erleap". He is clear that he would not be the king if he doesn't take extreme action. His horrible idea of murdering Duncan has shaped up in his mind at that time. That's why he says "Stars, hide your fires; Let not light see my black and deep desires". His ambition shows so obviously long before Lady Macbeth joins the plan. In addition, when Duncan stays at Macbeth's home, Macbeth has decided to kill the king before lady Macbeth enters. His soliloquy shows his inner thoughts:

If it were done when 'tis done,

then 'twere well it were done quickly.

If th' assassination could trammel up the consequence

and catch with his surcease success,

that but this blow might be the be-all and the end-all here....

Therefore, it is not Lady Macbeth who makes Macbeth have the idea of murdering the King.

Secondly, Lady Macbeth doesn't take any real action in murders. She only knows about murdering Duncan, and stays out of other murders. And she doesn't carry out the murder of Duncan. When facing two "surfeited grooms", Lady Macbeth says "Had he not resembled my father as he slept, I had done't". It shows that Lady Macbeth is not as evil as she thinks. She is too effeminate to kill the grooms. Killing Duncan is the only murder which Lady Macbeth takes part in, and she doesn't take any real actions. It shows she is not the devil who should be to blame for the tragedy. In addition, after being the king, Macbeth is always anxious about Banquo's children. Therefore, he orders two murderers to kill Banquo and his son Fleance. Lady Macbeth doesn't know anything about this plan. Only after Macbeth plans everything with two murderers, he mentions "a deed of dreadful note" to Lady Macbeth. She knows nothing and asks Macbeth "What' to be done?" and Macbeth only tells her she should "be innocent of the knowledge". Similarly, Macbeth is determined to kill the families of Macduff. "The castle of Macduff I will surprise, seize upon Fife, give to th' edge o'th'sword". His determination is shown clearly in his words. Lady Macbeth doesn't persuade Macbeth to murder them. It is Macbeth who does all the subsequent evil things.

Thirdly, compared with Macbeth, actually Lady Macbeth is not a real devil. By reading this tragedy, it is easy for readers to get an impression of Lady Macbeth. It is easy to neglect that Lady Macbeth is not strong and cruel as a woman at that time.[3] Lady Macbeth is widely regarded as a cruel and heartless woman.[4]This impression can be gotten from some behaviors of Lady Macbeth: 
The raven himself is hoarse

That croaks the fatal entrance of Duncan

Under my battlements. Come, you spirits

That tend on mortal thoughts, unsex me here,

And fill me from the crown to the toe top-full

Of direst cruelty! make thick my blood;

Stop up the access and passage to remorse,

That no compunctious visitings of nature

Shake my fell purpose, nor keep peace between

The effect and it! Come to my woman's breasts,

And take my milk for gall, you murdering ministers,

Wherever in your sightless substances

You wait on nature's mischief! Come, thick night,

And pall thee in the dunnest smoke of hell,

That my keen knife see not the wound it makes,

Nor heaven peep through the blanket of the dark,

To cry'Hold, hold!

In this part, Lady Macbeth lets devil occupy her heart and body, to make her cruel and fearless. She wants to get rid of gentleness as a woman so that she can efficiently carry out the plan of making Macbeth the King of Scotland. These words can leave an impression on the readers, which is that Lady Macbeth is fearless and heartless. And this impression can be strengthened by some other behaviors of Lady Macbeth. After Macbeth murders the King Duncan, he appears afraid of what he has done and they have a conversation:

\section{MACBETH:}

I'll go no more:

I am afraid to think what I have done;

Look on't again I dare not.

\section{LADY MACBETH:}

\section{Infirm of purpose!}

Give me the daggers: the sleeping and the dead

Are but as pictures: 'tis the eye of childhood

That fears a painted devil. If he do bleed,

I'll gild the faces of the grooms withal;

For it must seem their guilt.

\section{MACBETH:}

What hands are here? ha! they pluck out mine eyes.

Will all great Neptune's ocean wash this blood

Clean from my hand? No, this my hand will rather

The multitudinous seas in incarnadine,

Making the green one red.

\section{LADY MACBETH:}

My hands are of your colour; but I shame

To wear a heart so white.

In this conversation, when Macbeth shows fear of what he has done to the King Duncan, Lady Macbeth asks him to forget what he has done and be brave to shoulder the responsibility . And when Macbeth says his hands are bloody, Lady Macbeth says her hands are also bloody but she is not as afraid as Macbeth.

From these two examples, it seems that Lady Macbeth is cruel and heartless, and she is braver than Macbeth when the plan of murdering the King Duncan is carried out.

However, these are just what Lady Macbeth tries to show to her husband. It can be proved from some behaviors of Lady Macbeth in the later part of the tragedy.

Is it true that Lady Macbeth is fearless of the plan they carried out to kill the King Duncan? Actually, after the King Duncan is murdered by Macbeth, Lady Macbeth is tortured by the fear day and night, and finally died of madness. It can be found in some behaviors and words of Lady Macbeth. When Lady Macbeth is tortured by great fear and pressure, she does some strange behaviors:

\section{DOCTOR:}

What is it she does now? Look, how she rubs her hanas.

\section{GENTLEWOMAN:}

It is an accustomed action with her,to seem thus washing her hands: I have known her continue in this a quarter of an hour.

\section{LADY MACBETH:}

Yet here's a spot.

\section{DOCTOR:}

Hark! she speaks: I will set down what comes from Her, to satisfy my remembrance the more strongly.

\section{LADYMACBETH:}

Out, damned spot! Out, I say!--One; two; why, Then, 'tis time to do't. -- Hell is murky!-Fie, my Lord, fie! a soldier, and afeard!What need we fear who knows it, when none can call our power to account? --Yet who would have thought the old man to have had so much blood in him.

\section{DOCTOR:}

De you mark that?

\section{LADY MACBETH:}

The thane of Fife had a wife: where is she now?-What, will these hands ne'er be clean?--No more $o^{\prime}$ That, my lord, no more $o^{\prime}$ that: you mar all with this starting.

\section{DOCTOR:}

Go to, go to; you have known what you should not.

\section{GENTLEWOMAN:}

She has spoke what she should not, I am sure of That: heaven knows what she has known. 


\section{LADY MACBETH:}

\section{Here's the smell of the blood still: all the} perfumes of Arabia will not sweeten this little hand. Oh, oh, oh!

In this conversation, from the words of doctor and gentlewoman, and the words of Lady Macbeth, it can be found that Lady Macbeth is being tortured by her bloody hands. She wants to clean her bloody hands, the horrible memory and her fear.[5] She is so afraid of what she and Macbeth have done, which is a sharp contrast to what she says when the King Duncan is murdered. At that time, she says: "My hands are of your colour; but I shame to wear a heart so white." But at this moment, she says: "Here's the smell of the blood still: all the perfumes of Arabia will not sweeten this little hand." Besides, it can noticed that Lady Macbeth always have a lighting candle, which further indicates her great fear. She will become more afraid in the darkness because of what she has done.

From this sharp contrast, it is obvious that Lady Macbeth is not as fearless as what she behaves before. Her cruelty is just the disguise. She disguises herself in order to persuade her husband to carry out the plan.

After the King Duncan is murdered, Macbeth continues to murder many people regarded as his enemies, while Lady Macbeth is silently tortured by fear. But Lady Macbeth never shows her fear to Macbeth. In the contrast, Macbeth shows his fear to Lady Macbeth and gets comfort from his wife. For example, when the King Duncan is murdered, Macbeth shows his fear to Lady Macbeth by saying "I am afraid to think what I have done; Look on't again I dare not." And Lady Macbeth uses "Infirm of purpose!" to comfort him.

From the behaviors and words of Lady Macbeth, we can find that although she has ambitions, the purpose of what she does is to help her husband and she keeps silent for her fear in order not to disturb her husband. Therefore, it can be seen that Lady Macbeth loves Macbeth, and she pretends to be cruel and heartless for her husband. Actually Lady Macbeth is not a real devil but a woman pretending to be a devil. Her tragedy is because of the unbalance between her pretending cruelty and her weakness. [6]

\section{B. Macbeth and the Three Witches}

According to many Western critics, the tragedy of Macbeth is the result of the seduction of three witches. Obviously, the three witches play a vital role in the process of Macbeth's getting himself destroyed. In this tragedy, on the way home with the victory of war, Macbeth meets three witches. The first witch calls Macbeth Thane of Glamis, and the second calls him Thane of Cawdor. The third witch calls him the King of Scotland. After that, the news from the King informs Macbeth that he becomes the Thane of Glamis, which proves the predication of the first witch. This realization of the predication shocks the Macbeth and he starts his tragedy. It seems that it is the seduction and predication of three witches that cause Macbeth to the destruction and they are the primary factors of the cause of this tragedy. But they are not the primary factors. From some behaviors and words of Macbeth, we can find that Macbeth is not innocent but the main factor of this tragedy.

Firstly, the witches just speak out the inner evil ambitions of Macbeth. After the predication of the first witch is realized, Macbeth says to Banquo:

\section{Do you not hope your children shall be kings, When those that gave the thane of Cawdor to me Promised no less to them?}

By saying these words, it is obvious that Macbeth shows great interests on the Throne of King. If Macbeth is a good subject who is loyal to his king without any ambition to replace the king, Macbeth will not shows such great interests on the predication of the three witches. But he does, which indicates that in the bottom of Macbeth's heart, there is evil and great ambition which mainly causes this tragedy. From this, we can infer that Macbeth is not satisfied with what he has before becoming the king, and he just hides his evil in the heart.

And Macbeth wants to know more about the predication from the three witches. Macbeth says:

\section{Stay, you imperfect speakers.}

\section{Tell me more}

His words express that he has already got the desire to be the king before the appearance of witches and he wants to get more information from witches. He is so eager to know details about three titles that he even demands witches to answer him.

\section{Say from whence you owe this strange intelligence or why upon this blasted heath you stop our way with such prophetic greeting. Speak, I charge you.}

As three witches vanish without answering his questions, he says, "Would they had stayed! "

His soliloquy shows his urgent eager to know whether he will become the king or not. Besides, he calls the words of witches "prophetic greeting", it clearly shows he has already thought to be the king and believes it must come true.

In addition, Macbeth is so concentrated on the "prophetic greeting" that he doesn't forget the words of witches after they vanish. It manifests Macbeth strong disloyalty to Duncan. When Ross tells Macbeth

\section{He bade me, from him, call thee Thane of Cawdor, In which addition, hail, most worthy thane, For it is thine}

Macbeth is so excited that he cannot control himself. At that time, he is sure the last prediction would come true. It is shown clearly in his words, "Glamis and Thane of Cawdor! The greatest is behind". If he has no ambition to be the king, how can the words of witches have such great influence on him? The reason why he trusts witches so much is that his existed evil ambition is supported. He has the great ambition of being the king before three witches tell him. Compared the reactions of Macbeth and Banquo, both of them are predicted to be honorable. After knowing the first and second predictions both come true, Macbeth begins to imagine his future life as the king. However, Banquo is loyal to Duncan 
and doesn't believe in the witches, and even doubts the righteousness of them. Macbeth feels so excited and thinks Banquo would be as excited as he is, so he implies Banquo, "Do you not hope your children shall be kings". However, Banquo has doubted witches and he says,

But 'tis strange. And oftentimes, to win us to our harm, the instruments of darkness tell us truths,

win us with honest trifles,

to betray 's in deepest consequence.

Through analyzing the sharp contrast between the reaction of Macbeth and Banquo, it is clear that Macbeth has already desired to be the king, but Banquo is loyal to Duncan. It is not witches trigger Macbeth to pursue the throne. They only further make Macbeth believe that his dream must come true.

Macbeth's strong determination of being the king is also shown when Duncan proclaims that

We will establish our estate upon out eldest, Malcolm, whom we name hereafter the Prince of Cumberland Macbeth says:

The Prince of Cumberland!

That is a step on which I must fall down or else o' erleap...

The eye wink at the hand,

yet let that be which the eye fears,

when it is done, to see"

It is obvious that Macbeth determines to wipe out every obstacle to get the throne. He wants to do so even without the lure from witches. Three witches don't change Macbeth, but only support his ambition and make Macbeth more firmly believe in his ambition.

Secondly, the witchcraft of three witches is not powerful enough. In Act. I, Scene. III, the first witch is abused by a sailor's wife, she wants to revenge her. However, she has no enough power to do that. Therefore, she needs the other two witches to give her wind. Even so, "his bark cannot be lost". In addition, In Act. III, Scene.V, three witches meet Hecate. From what Hecate says, three witches are inferior. As Hecate says to them, "And I, the mistress of your charms, the close contriver of all harms". Besides, three witches are afraid of Hecate. After Hecate leaves with anger, they say, "Come, let's make haste. She'll soon be back again". Therefore, it is shown that the status of three witches is not high. How can such incapable and secondary witches change the mind of Macbeth and instigate him to murder the king. The main reason why Macbeth takes all the evil actions is his own evil ambition and instead of lure from three witches.

\section{PRINCIPAL RESULTS}

From the analysis, we can get the results that Lady Macbeth and three witches should not bear principal responsibility for the tragedy and they just play secondary roles in the process of Macbeth's getting himself destroyed. Before they instruct or lead Macbeth to carry out the murders, the evil ambitions have existed in the bottom of Macbeth's heart. Besides, they never participate in the murders.

\section{MAJOR CONCLUSIONS}

From the results from the analysis, it can be concluded that Macbeth himself is the primary factor of leading to the tragedy in Macbeth. Lady Macbeth and the three witches are the secondary factors. Without the evil ambitions, Macbeth will not be seduced by Lady Macbeth and the three witches. Macbeth is not innocent but a real devil in making this tragedy which destroys many people and him.

\section{REFERENCES}

[1] M. Cheng, "Plot analysis on Macbeth," Journal of Lanzhou Institute of Education, 2017.

[2] S. Liang. "The tragic factors in Macbeth," Journal of Wenxue, 2017.

[3] L. Jiang, "Comments on Lady Macbeth," Home Drama, 2016.

[4] Y. Kuang, "Under the veil of evil: Lady Macbeth," Journal of Mianyang Teachers' College, 2018.

[5] J. Xu, "Analysis on the tragedy of Lady Macbeth," Anhui Literature, 2017.

[6] J. Li, "Analysis on the Characters of Macbeth," Language Planning, 2016.

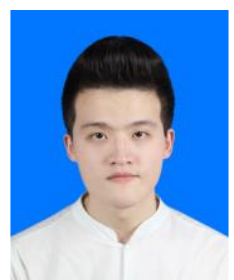

Zhang Tong was born on June 18th, 1995, Fuzhou city, Fujian province, China.

He has got his bachelor of arts in Northwestern Polytechnical University, Xi'an, China, in June, 2017. And he is pursuing the master's degree, majoring in applied linguistics in Northwestern Polytechnical University since September, 2017. His major Field of study is dialects.

He was a teaching assistant in the Middle School Attached to Northwestern Polytechnical University during March and April in 2017, and an assistant of Foreign Affairs Office of People's Government of Shaanxi Province. His current research interests include dialects.

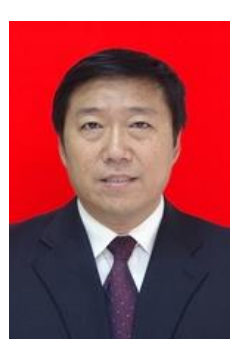

Tian Jianguo was born in June, 1959, in China. He has got his bachelor of English language and literature from Xi'an International Studies University, Xi'an, China, in July, 1983; the master of education from Emporia State University, Kansas State, the United States, in August, 1995.

His major field of study includes sociolinguistics and applied linguistics.

He was a teacher in Northwest Forestry College from 1983 to 1986. And from 1986 to 1992, he was the member of the faculty of Northwestern Polytechnical University; from 1992 to 1997, the visiting scholar in Emporia State University. From 1997 to today, he has been the professor of Northwestern Polytechnical University. From 2008 to 2013, he was the vice dean of College of Humanities and Law of Northwestern Polytechnical University. From 2013 to 2017, he was the vice dean and secretary of the Party committee of the School of Foreign Studies of Northwestern Polytechnical University. His previous publications includes: 1. Tian Jianguo, "Study on Vocabulary Learning Strategies from the Psycholinguistic Perspective Based On the Bilingual Mental Lexicon Structure", Foreign Language World, 2012(02):74-80. 2. Tian Jianguo, "Research on College English Writing on the Macro Discourse Level Based on Web Resourcers." Advances in Computer Science, Environment, Ecoinformatics and Education International Conference, CSEE 2011, Wuhan, China, August 2011. 3. Tian Jianguo, "Re-reflection on Cultural Context", Journal of Northwestern Polytechnical University (Social Sciences), 2012 (03):77-81+104. His current and previous research interests are sociolinguistics and applied linguistics.

Prof. Tian Jianguo is vice-chairman of the Association of Foreign Language Teaching in University Research of Shaanxi Province and Shaanxi Translators' Association. He is the member of Chinese Engineering Master's English Expert Group. 


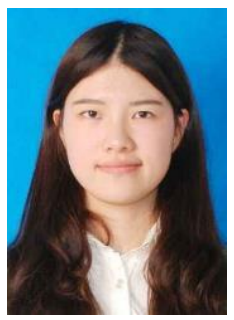

Wang Fangyuan was born in Hefei city, Anhui province in China on March 1st, 1995. She has got the bachelor's degree in Northwestern Polytechnical University, Xi'an city, China in June, 2017 with majored in English. She is pursuing for master's degree in Northwestern Polytechnical University since September, 2017, major in English literature now. Her major study field includes space narration, children literature, and immigrant literature.

She was a teaching assistant in the Middle School Attached to Northwestern Polytechniacal University during March and April in 2017; TOEFL teaching assistant in New Oriental during July and August in 2017; Internship in the People's Government of Shaanxi Province in winter vacation in 2018 . 